\title{
Evaluation of the Ethyl Acetate Extract of the Roots of Avicennia marina as Potential Anticancer Drug
}

\author{
Immanuel B. Tanjung ${ }^{1}$, Norma N. Azizah², Ade Arsianti ${ }^{2}$, Amalda S Anisa ${ }^{3}$, Kholis
}

A Audah ${ }^{1,4, *}$

\author{
${ }^{1}$ Department of Biomedical Engineering, Swiss German University, Tangerang, 15143, Indonesia \\ ${ }^{2}$ Drug Development Research Center, IMERI, University of Indonesia, Jakarta, 10430, Indonesia \\ ${ }^{3}$ Department of Chemistry, IPB University, Bogor, 16680, Indonesia \\ ${ }^{4}$ Directorate of Academic Research and Community Service, Swiss German University, Tangerang, 15143, Indonesia \\ *Corresponding author.Email: audahka@gmail.com
}

\begin{abstract}
In this modern age cancer is still a prevalent disease. Even with advancements of technology, current treatments for cancer still have various side-effects that sometimes create more harm to the patient. A complete solution for cancer is still not found yet. Recently, mangroves were shown to be promising sources of new drugs. The species Avicennia marina was suggested to be anti-cancerous, thus it could be a potential anticancer drug. This study was conducted to evaluate the viability of $A$. marina root ethyl acetate extract as a possible anticancer drug, and to determine whether its anticancer mechanisms are by counteracting the reactive oxygen species as an antioxidant. The extract was subjected to total phenolic and flavonoid content tests, to determine the bioactive compounds, which are thought to be directly related to antioxidant activities. The DPPH method was used to evaluate the antioxidant activity of the extract. Brine shrimp (Artemia salina) was subjected to the extract to determine its toxicity, and determined its anticancer properties against cancer cell lines HT29 (colon), HeLa (cervix) and T47D (breast) by MTT Assay. Results showed that the extract has moderate amounts of phenolic and flavonoids, moderate antioxidant activity, not toxic to normal cells but toxic towards cancer cells.
\end{abstract}

Keywords: Antioxidants, Avicennia marina, Bioactive, Cancer, MTT assay.

\section{INTRODUCTION}

Cancer is a second cause of death in the United States after cardiovascular diseases in 2019 according to the Centers for Disease Control and Prevention (CDC), as well as the top four leading causes of death in different countries globally according to estimates from the World Health Organization (WHO) [23]. The number of cases of cancer globally is expected to keep rising in the future, with some estimates as high as $47 \%$ increase in global cases in 2040 [23, 5]. Thus, it is of high importance that a cure for cancer is found, in order to reduce and potentially eradicate the cases of cancer and also deaths by cancer.

Various treatments have been made to cure cancer, including surgery, chemotherapy, radiotherapy, and targeting therapy. But all of these procedures have side effects, such as anemia, malaise, vomiting, susceptibility with infection, even, for radiotherapy treatment can cause an adverse effect on other healthy cells [12]. Natural ingredients have attracted the interest of some researchers as they have shown to have minimal to no side effects $[19,12]$ and that approximately half of drugs approved by the Food and Drug Administration (FDA) came from natural ingredients.

Around $80 \%$ of anticancer drugs came or mimic natural ingredients [18]. In recent years, mangroves have been of interest to scientists and researchers lately due to its peculiar habitat, which might indicate they have chemical compounds or secretes chemical compounds that help them thrive in harsh conditions that could be useful for humans. This is proven by studies and was reviewed in 2002, stating that there are various chemicals that can be characterized from mangroves, and that each mangrove plant has different chemicals [3]. A species of mangrove, A. marina (Figure 1), has shown that it contains bioactive compounds that are an effective cytotoxic and show antitumor characteristics [8]. It has 
also been studied as a potential anticancer material by testing it against several lines of cancer cells [22]. Screenings have shown positive results, which indicates that it might be a possible source of an anticancer drug.

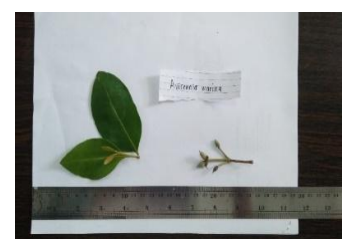

(a)

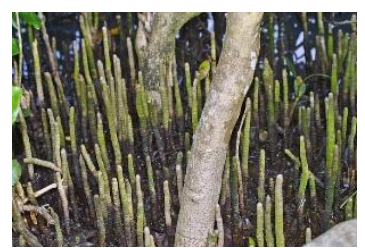

(b) $\begin{array}{ll}\text { Kingdom } & \text { : plantae } \\ \text { Genus } & : \text { Avicennia } \\ \text { Family } & : \text { Acanthaceae } \\ \text { Species } & : \text { Avicennia marina } \\ \text { Similar name } & \text { : grey mangroves or white mangroves }\end{array}$ Figure 1. Morphology of Avicennia marina (a) leaves (b) Root (source: personal document)

This study was conducted to evaluate the viability of A. marina root ethyl acetate extract as a possible anticancer drug, and to determine whether its anticancer mechanisms are by counteracting the reactive oxygen species as an antioxidant.

\section{MATERIALS AND METHOD}

\subsection{Extraction Sample of A. marina Root}

About $1000 \mathrm{~g}$ of dry powder samples of $A$. marina root were macerated in ethyl acetate in a sealed glass vessel for 24 hours with three replicates. After 24-hour filtrate was filtered using filter paper. Maceration was done three times to get as many extracts as possible. After maceration, the filtrates were evaporated to obtain concentrated extract of A. marina.

\subsection{Evaluation of Total Phenolic Content}

The method described is adapted from Audah et al. [2]. The sample was taken $0.5 \mathrm{ml}$ and mixed with $1 \mathrm{ml}$ of sodium carbonate $(2 \% \mathrm{w} / \mathrm{v})$ and $0.5 \mathrm{ml}$ of Folin-Ciocalteu reagent $(10 \% \mathrm{v} / \mathrm{v})$. The solution was mixed by using a vortex at each step and incubated for half an hour in a dark chamber. Absorption was measured using UV-Vis spectrophotometer at $765 \mathrm{~nm}$. A standard curve made of Gallic acid was prepared by diluting 1000 ppm stock solution with $75 \%$ ethanol solution to yield $0,6.25,12.5$, $25,50,100,200 \mathrm{ppm}$. The results were calculated according to the standard curve and are expressed as both ppm and milligram Gallic Acid Equivalent per gram extract (mg GAE/g extract).

\subsection{Evaluation of Total Flavonoid Content}

The method described is also adapted from Audah et al. [2]. The sample was taken $0.15 \mathrm{ml}$ and was mixed with $0.45 \mathrm{ml} 75 \%$ ethanol. The solution was vortexed to ensure thorough mixture and then the sample was mixed with $0.03 \mathrm{ml}$ of $10 \%$ aluminum chloride, vortexed and then added $0.03 \mathrm{ml}$ of $1 \mathrm{M}$ potassium acetate and lastly mixed with $0.84 \mathrm{ml}$ distilled water. The mixture was then vortexed and incubated in a dark chamber for 30 minutes. The absorbance was measured using the UV-Vis spectrophotometer at $415 \mathrm{~nm}$. The standard curve was made with quercetin and was prepared by diluting the $1000 \mathrm{ppm}$ stock with the $75 \%$ ethanol to yield $0,6.25$, $12.5,25,50,100,200 \mathrm{ppm}$. The results were calculated according to the standard curve and expressed as both ppm and milligram Quercetin Equivalent per gram extract (mg QE/g extract).

\subsection{Evaluation of Antioxidant Activity with DPPH Method}

The method described was adopted from Manuella et al. [17]. Stock solutions of $100 \mathrm{ppm}$ DPPH $(\mathrm{Mr}=394.32$ $\mathrm{g} / \mathrm{mol}$ ) were prepared by diluting $10 \mathrm{mg}$ of DPPH powder in ethanol $75 \%$ to reach the final volume of $100 \mathrm{ml}$. In aluminum foil covered test tubes, samples with concentrations of $6.25,12.5,25,50,100 \mathrm{ppm}$ were prepared by adding $75 \%$ ethanol until $0.75 \mathrm{ml}$. Ascorbic acid solutions as positive control were also created with the same concentrations. Then, $750 \mu \mathrm{L}$ of $100 \mathrm{ppm}$ DPPH solution were added to each of the test tubes and then vortexed. Controls were prepared by creating DPPH solutions of equal concentrations as the samples. The blank was made using $1.5 \mathrm{ml}$ of $75 \%$ ethanol. The test tubes were incubated in a dark chamber for 30 minutes at room temperature. Absorbance was read at $517 \mathrm{~nm}$ using the UV-Vis spectrophotometer. The result is expressed as Inhibition Concentration at $50 \%\left(\mathrm{IC}_{50}\right)$. There are five categories of antioxidant activity, namely very strong (range $<50 \mathrm{ppm}$ ), strong (range $50-100 \mathrm{ppm}$ ), moderate (range 101-250 ppm), low (range 251-500 ppm), and inactive (range $>500 \mathrm{ppm}$ ) [14].

\subsection{Brine Shrimp Lethality Test}

The Brine Shrimp Lethality Test was adopted from Harwig J, Scott PM [15]. Samples were given $20 \mu \mathrm{L}$ Tween-80 and made into concentrations of 1600,800 , $400,200,100,50,25,12.5,6.25,3.125,1.5625 \mathrm{ppm}$ by adding seawater until $1 \mathrm{ml}$ in each well. Each well was given $10 \mathrm{~A}$. salina that had been grown previously and observed after 24 hours, 48 hours, and 168 hours. The amount of nauplii that survived will determine the sample's Lethal Concentration 50\% ( $\left.\mathrm{LC}_{50}\right)$.

\subsection{In Vitro Cytotoxicity Assay (MTT Assay)}

In Vitro Cytotoxicity Assay (MTT Assay) was adopted from Mosmann, T [16]. Cell lines (Cervix cancer 
(HeLa), colon cancer (HT29), breast cancer (T47D)) are going to be inoculated on the wells with their respective media, with $100 \mu \mathrm{L}$ complete growth media per well, with each well containing 10000 cells. A series of concentrations from $1000,500,250,125,62.5,31.25$, $15.625,7.8125 \mathrm{ppm}, 100 \mu \mathrm{L}$ of active extract will be added to the inoculant and are going to be incubated for 24 hours in incubator at $\mathrm{CO}_{2} 5 \%, 37^{\circ} \mathrm{C} .100 \mu \mathrm{L}$ of monoculture tetrazolium salt (MTT) will be added and re-incubated for 4 hours. Living cells will react with the MTT and form purple-colored formazan. Formazan formed will be dissolved in Dimethyl Sulfoxide (DMSO) and will be read by spectrophotometer at $595 \mathrm{~nm}$.

\section{RESULTS AND DISCUSSION}

\subsection{Phenolic Content of A. marina Root Extract}

Total phenolic content test results indicated that A. marina root extract contains small amounts of phenolic compounds, which, according to Batubara et al. [4], the phenolic compounds contained in the leaf extract are saponin and steroid. However, according to Das et al. [8], the plant A. marina should contain some types of quinones. The quantified result is shown in table 1 below. The plant A. marina contains $24.8667 \pm 0.782901 \mathrm{ppm}$ or $\mathrm{mg} \mathrm{GAE} / \mathrm{g}$ extract total phenolic contained within 1 $\mathrm{mg} / \mathrm{ml}$ (1000 ppm) sample, a value obtained from a linear equation that UV-Vis spectrophotometer produced, which is $\mathrm{y}=0.0115 \mathrm{x}+0.04726$. This value gives a yield of $2.48 \%$.

Table 1. Phenolic content of $A$. marina root extract

\begin{tabular}{ccc}
\hline $\begin{array}{c}\text { Phenolic Content } \\
\text { (mg GAE } / \mathbf{g})\end{array}$ & Yield (\%) & Category \\
\hline $24.86 \pm 0.78$ & 2.48 & Moderate \\
\hline
\end{tabular}

The quantity of phenolic compounds is in accordance with previous studies $[4,8]$, which found only a small quantity of bioactive compounds. Despite the seemingly small amount, it is categorized as moderate according to Qusti et al. [21]. Saponin content is further examined by conducting a qualitative saponin test, which resulted in no saponin detected in the sample. This result is in contrast to Batubara et al. [4], however, it is in line with the research of Khafagi et al. [17] which stated that no traces of saponin is found in their A. marina sample. A much more rigorous characterization of the chemicals contained within the sample, possibly also fractionation, is required to be done in the future in order to determine the phenolic contents of the mangrove A. marina.

\subsection{Flavonoid Content of A. marina Root Extract}

This research conducted two types of flavonoid tests, quantitative and qualitative. Quantitative flavonoid tests results are shown in Table 2 below. Quantitative
Flavonoid content tests have shown that A. marina contains $15.9467 \pm 1.572938 \mathrm{ppm}$ or $\mathrm{mg} \mathrm{GAE} / \mathrm{g}$ extract of flavonoid contained within $1 \mathrm{mg} / \mathrm{ml}(1000 \mathrm{ppm})$ sample, a value obtained from a linear equation that UVVis spectrophotometer produced, which is $\mathrm{y}=0.00736 \mathrm{x}$ - 0.01523 , which gives a yield of $1.59 \%$ (Table 2). The results of the study can be categorized as moderate level, following the total phenolic content grouping, namely High (Range $>70 \mathrm{mg} \mathrm{GAE} / \mathrm{g}$ extract), moderate (Range 10-70 mg GAE/g extract) and low (Range $<10 \mathrm{mg} \mathrm{GAE} / \mathrm{g}$ extract) [23].

Table 2. Flavonoid content of A. marina root extract

\begin{tabular}{ccc}
\hline $\begin{array}{c}\text { Flavonoid Content } \\
\text { (mg QE/g) }\end{array}$ & Yield (\%) & Category \\
\hline $15.95 \pm 1.57$ & 1.59 & Moderate \\
\hline
\end{tabular}

However, this result is contradicted by the qualitative flavonoid test, which turned out negative. The negative result is supported by Batubara et al. [4], however, it could be a potential false negative due to the quantity of flavonoids in the sample. A more sensitive qualitative flavonoid test could be conducted in the future, otherwise characterization of the chemicals could provide more data regarding whether there actually are flavonoid contained in the mangrove

\subsection{Antioxidant Activity of A. marina Root Extract}

Antioxidant activity test of $A$. marina root extract was carried out by the DPPH method. The basic principle of this method is that the DPPH solution which is purple will change color to yellow if it reacts with antioxidant compounds. The color change results in a decrease in absorbance at a wavelength of $517 \mathrm{~nm}$. Antioxidant activity tests were also carried out on ascorbic acid as a positive control for comparison.

Table 3. Antioxidant activity of $A$. marina root extract

\begin{tabular}{cccc}
\hline \multirow{3}{*}{ Sample } & \multicolumn{3}{c}{$\mathrm{IC}_{50}(\mathrm{mg} / \mathrm{mL})$} \\
& $\begin{array}{c}\mathrm{IC}{ }_{50} \\
(\mathrm{ppm})\end{array}$ & $\begin{array}{c}\mathrm{DPPH} \\
\text { Inhibition }(\%)\end{array}$ & Category \\
\hline $\begin{array}{c}\text { Avicennia } \\
\text { marina }\end{array}$ & $\begin{array}{c}150.91 \pm \\
27.19\end{array}$ & 43.92 & Moderate \\
\hline $\begin{array}{c}\text { Ascorbic } \\
\text { acid }\end{array}$ & $\begin{array}{c}2.31 \pm \\
0.10\end{array}$ & 96.33 & $\begin{array}{c}\text { Very } \\
\text { Strong }\end{array}$ \\
\hline
\end{tabular}

The absorbance obtained from the sample concentration series was converted into \% inhibition of $\mathrm{DPPH}$, which then made an equation curve between the concentration of $\%$ inhibition to determine the $\mathrm{IC}_{50}$ value, short for $50 \%$ inhibitory concentration of free radical activity, of A. marina extract. The smaller the $\mathrm{IC}_{50}$ value of a substance or test sample the better the antioxidant activity of the ingredient.

The results are shown in table 3 . Results put the sample in moderate range (101-250 ppm) [14]. This 
moderate antioxidant activity could be caused by the phenolic compounds as well as the flavonoid compounds that were detected in the sample, as antioxidant properties have been linked to be caused by these compounds [9, $10]$.

\subsection{Toxicity of A. marina Root Extract}

Toxicity evaluation was done using the brine shrimp lethality test (BLST) with Artemia salina L. shrimp larvae as test subjects. The mortality rate of the subjects was calculated after the 24-hour incubation period ended. The resulting percentage of mortality rate of the subjects was $0 \%$ at the highest extract concentration $(1500 \mathrm{ppm})$ and every concentration below.

This result can be interpreted as there is no risk of death equal to a concentration of $1500 \mathrm{ppm}$. This is supported by negative control, i.e the shrimp larvae are given a sample without death after 24 hours incubation. Several shrimp larvae were found to be faster and active after being treated by the sample and a 24-hour incubation period. This relates to mangrove extracts which provide nutrition against $A$. salina because some mangroves are used as a food source for humans [18]. This effect could possibly be contributed by the steroidal compounds contained in the sample, as steroids have been used to treat wasting conditions [11], but future research should be done in order to obtain further insight regarding this phenomenon.

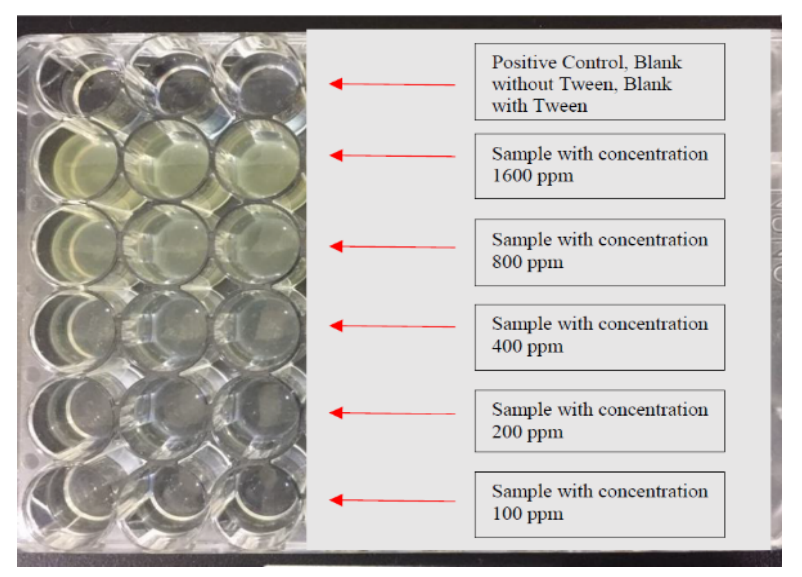

Figure 2. BSLT Test Documentation.

The BSLT method is used to see the toxicity level of an ingredient is to the shrimp larvae, with the end result of this test is to obtain a $50 \%$ Lethal Concentration $\left(\mathrm{LC}_{50}\right)$ value. $\mathrm{LC}_{50}$ is the concentration of the sample extract that causes the death of shrimp larvae by $50 \%$ after 24 -hour incubation. Based on the research results of the A. marina extract toxicity test, because the percent of mortality at the highest concentration is zero percent, it can be concluded that the A. marina root extract has an $\mathrm{LC}_{50}>$ $1500 \mathrm{ppm}$.

According to Clarkson et al. [6], the mangrove extract in this experiment has a non-toxic level of toxicity because the $\mathrm{LC}_{50}$ value of the sample is greater than 1000 $\mathrm{ppm}$. This is in line with the goal, as the mangrove extract used as the sample potentially contains bioactive compounds that are safe (non-toxic) for use as a drug ingredient. The test can be seen in Figure 2.

\subsection{Cytotoxic Activity of A. marina Root Extract Against Cancer Cell Lines}

The effectiveness of flavonoids is widely studied in its interactions with many pathways to disease inhibition, especially in antioxidant and anticancer activities. There are several mechanisms associated with SAR flavonoids in treating cancer, namely induction of apoptosis, cytotoxicity, inhibition of receptors and metabolism, inhibition of carcinogenic enzymes and induction of differentiation $[13,22,26]$.

The method used in this study is cytotoxicity. Cytotoxicity tests are standardized evaluations to determine whether an ingredient contains biologically dangerous substances. One method commonly used for cytotoxicity testing is MTT. The principle of this method is the reduction of yellow salt tetrazolium of MTT (3(4,5-dimethyltyliazol-2-il)-2,5-diphenyltetrazolium bromide) by the reductase system. Tetrazolium succinate which belongs to the respiration chain in the mitochondria of living cells forms purple formazan crystals and is insoluble in air. Addition of stopper reagent (detergent in nature) will dissolve this colored crystal which is then absorbed using a UV/VIS spectrophotometer with a wavelength of $595 \mathrm{~nm}$. The intensity of the purple color is proportional to the number of living cells. The higher the purple color, the greater the number of living cells.

Anticancer cytotoxic test in this study was conducted on 3 types of cancer cell lines including breast cancer cells (T47D), cervical cancer cells (HeLa), and colorectal cancer cells (HT29). In addition, cytotoxicity tests on normal cells hADSC (human adipose derived stem cells) were used as a comparison. MTT Assay results showed that the extract is non-toxic to the mesenchymal/human adipose derived stem cell. Result shows that the absorbance values from the sample are almost the same as the cell and medium control (the negative control), that could be interpreted as most cells are still viable just like the negative control, which are untreated (Table 4).

Table 4. $\mathrm{IC}_{50}$ value of citotoxic test agains cancer cells and normal cells

\begin{tabular}{ccccc}
\hline \multirow{2}{*}{ Sample } & \multicolumn{4}{c}{$\mathrm{IC}_{50}(\mathrm{mg} / \mathrm{mL})$} \\
\cline { 2 - 5 } & $\begin{array}{c}\text { Stem cell } \\
\text { hADSC }\end{array}$ & $\begin{array}{c}\mathrm{HT} 29 \\
\text { Cells }\end{array}$ & $\begin{array}{c}\text { HeLa } \\
\text { Cells }\end{array}$ & $\begin{array}{c}\text { T47D } \\
\text { Cells }\end{array}$ \\
\hline $\begin{array}{c}\text { Avicennia } \\
\text { marina }\end{array}$ & - & 12.17 & 22.76 & 163.61 \\
\hline Cisplatin & 12.68 & 115.91 & 1.86 & 31.08 \\
\hline
\end{tabular}


Table 4 and Figure 3 shows the results of A.marina extract cytotoxicity test on three cancer cells and normal cells. The plant $A$. marina extract gives a cytotoxic effect on the three cancer cells with the best $\mathrm{IC}_{50}$ value, namely to colorectal cancer cells (HT29), with the smallest IC $_{50}$ value among the $\mathrm{IC}_{50}$ of other cancer cells, significantly less than the control cisplatin (CDDP). Since the $\mathrm{IC}_{50}$ value indicates the $50 \%$ inhibitory effect of cancer cell growth, the smaller $\mathrm{IC}_{50}$ is desirable because with a small concentration the cancer cell growth can be inhibited by as much as $50 \%$.

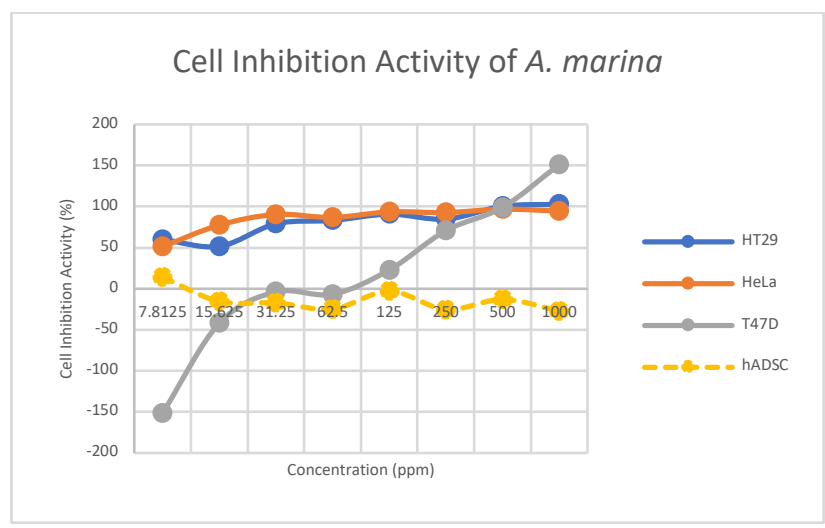

Figure 3. Cell inhibition effects of sample towards 3 cancer cell lines HT29, HeLa, T47D, and normal cell line hADSC.

Normal cells were treated with the same series of extract concentrations as the cancer cells, and the results shows that the extract did not provide inhibitory effects. Instead of inhibiting growth, the results suggest that it activates and invigorates the cells to allow proliferation, albeit results showing not consistently enough to create a high correlation, it still shows that most of the sample proliferated (Figure 4).

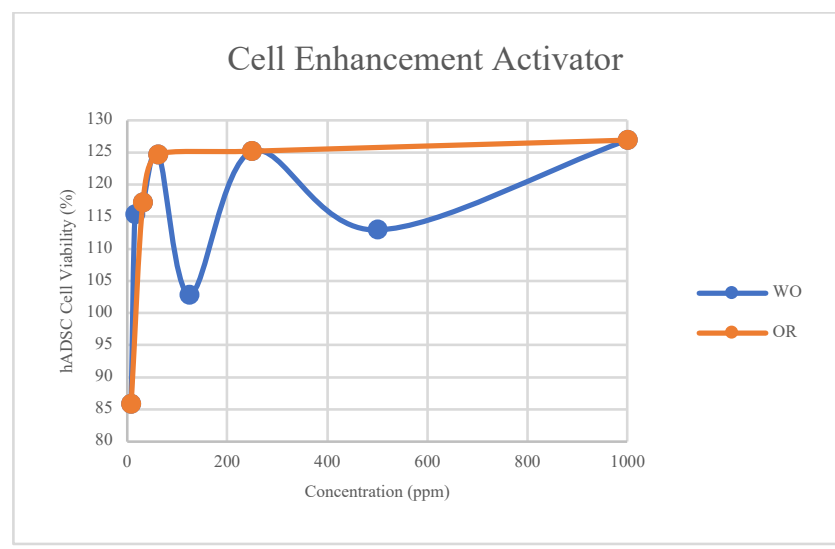

Figure 4. Cell enhancement activity of hADSC. WO indicates data including outliers, OR indicates data

The level of anticancer activity in the extract was grouped into 4 categories, namely active $\left(\mathrm{IC}_{50}\right.$ range $<20$ $\mathrm{mg} / \mathrm{mL}$ ), moderately active ( $\mathrm{IC}_{50}$ range $>20-100$ $\mathrm{mg} / \mathrm{mL}$ ), weak $\left(\mathrm{IC}_{50}\right.$ range $>100-1000 \mathrm{mg} / \mathrm{mL}$ ) and not active ( $\mathrm{IC}_{50}$ range $>1000 \mathrm{mg} / \mathrm{mL}$ ) [1]. Based on this, $A$. marina mangrove root extract has more potential to inhibit the growth of HT29 colorectal cancer cell lines with the active category. However, it does not rule out the possibility of inhibiting cervical and breast cancer cell growth, because based on Table 4 the $\mathrm{IC}_{50}$ value of mangrove extracts against cancer cells is in the range of $20-100 \mathrm{mg} / \mathrm{mL}$, which is moderate inhibition activity for cervical cancer cell line HeLa, and 100-1000 mg / mL, which is weak inhibition activity for breast cancer cell line T47D.

In addition to using $A$. marina's roots ethyl acetate extract as a potential anticancer drug, anticancer drug research can be done with other mangrove spesies. One of them is Xylocarpus granatum which can also be used as a potential anticancer drug. The extract $X$. granatum was found to be capable of inhibiting breast cancer cells (T47D), cervical cancer cells (HeLa), colorectal cancer cells (HT29). In addition, normal cells hADSC (human adipose derived stem cells) were used as a comparison. Tests of the extract were performed by using MTT cytotoxicity assay to determine extract efficacy compared with CDDP against several cell lines. The cytotoxicity result for $X$. granatum were similar to the cytotoxicity result for A. marina. Anticancer activity from $X$. granatum was found to be present in extract with the highest potency reached against colorectal cancer HT29 (Table 5), with extract anticancer IC 50 .

Table 5. Anticancer $\mathrm{IC}_{50}$ for extract and $\mathrm{CDDP}$ against cancer cells

\begin{tabular}{ccccc}
\hline \multirow{2}{*}{ Sample } & \multicolumn{4}{c}{ Anticancer MTT cytotoxity $\mathrm{IC}_{50}(\mathrm{ppm})$} \\
\cline { 2 - 5 } & hADSC & HT-29 & HeLa & T47D \\
\hline \multirow{5}{*}{ Activator } & & & \\
granatum & $(>73.8)$ & $42.50 \pm$ & $559.57 \pm$ & $77.76 \pm$ \\
& Inhibitor & 36.56 & 857.79 & 66.70 \\
& $(<73.8)$ & & & \\
\hline Cisplatin & $12.68 \pm$ & $115.91 \pm$ & $1.86 \pm$ & $31.08 \pm$ \\
(CDDP) & 4.59 & 32.47 & 1.38 & 13.95 \\
\hline
\end{tabular}

This suggested that the extracts of $X$. granatum had was successfully delivered to both hADSC and cancer cell lines due to the antioxidant compound's structures which was said to be lipophilic. Anticancer activity of extract was attributed to the phenolic configuration and side groups of flavonoids, similar to its antioxidant activity yet to be known for its exact mechanism [7] .

\section{CONCLUSION}

Ethyl acetate root extract of Avicennia marina have shown to have moderate bioactive compounds and antioxidant activity. The extract is also non-toxic towards normal cells, as indicated by brine shrimp lethality test and MTT assay towards normal cells, but highly toxic towards the cancer cell lines used in this study, namely HT29, HeLa and T47D cell lines. The sample seemed to have a compound that can specifically target specific cancer cell lines, or a group of compounds that do so. Since it is highly specific and non-toxic towards normal 
cells, it has potential to be further developed as an anticancer drug, although not for all cancer types tested.

\section{ACKNOWLEDGMENTS}

The authors would like to thank the Ministry of Research, Technology and Higher Education, Republic of Indonesia for the research grant under contract Number: AGMT/Rec/A0011/III/2019. The authors thank the Swiss German University for financial support through the Central Research Fund and the Faculty Research Fund. The authors also like to thank the IPB University and the Indonesian Medical and Research Institute, Faculty of Medicine, University of Indonesia for allowing us to use their laboratory facilities

\section{REFERENCES}

[1] Atjanasuppat, K., Wongkham, W., Meepowpan, P., Kittakoop, P., Sobhon, P., Bartlett, A., and Whitfield, P.J. 2009. In vitro screening for anthelmintic and antitumour activity of ethnomedicinal plants from Thailand. J.Ethnopharmacol. 123, pp.475-482.

[2] Audah, K. A. J., Syamsir, F., Almasyhur, A. M., Hapsari, H., and Sutanto. 2018. Development of Extract Library from Indonesian Biodiversity: Exploration of Antibacterial Activity of Mangrove. Bruguiera cylindrica Leaf Extracts. IOP Conf. Ser.: Earth Environ. Sci. 130012025

[3] Bandaranayake, W. M. 2002. Bioactivities, bioactive compounds and chemical constituents of Mangrove Plants. Wetlands Ecology and Management. 10, pp.421-452. Doi: 10.1023/A:1021397624349.

[4] Batubara, R., Amsyir, J., Himawan, S., Batubara, I., and Audah. K. A. 2018. Anticancer Screening of Mangrove Extract Library: Accelerating Drug Discovery from Indonesian Biodiversity. Proceedings of the International Conference on Innovation, Entrepreneurship and Technology.

[5] Bray, F., Ferlay, J., Soerjomataram, I., Siegel, R. L., Torre, L. A., and Jemal, A. 2018. Global cancer statistics 2018: GLOBOCAN estimates of incidence and mortality worldwide for 36 cancers in 185 countries. CA: A Cancer Journal for Clinicians. 68(6), pp.394-424.

[6] Clarkson, C., Maharaj, V. J., Crouch, N. R., Grace, O. M., Pillay, P., Matsabisa, M. G., Bhagwandin, N., Smith, P. J., and Folb, P. I. 2004. In vitro antiplasmodial activity of medicinal plants native to or naturalized in South Africa. Journal of Ethnopharmacology. 92(2-3), pp.177-191.
[7] Darmadi, J., Batubara, R., R., Himawan, S., Azizah N., N., Audah, K., H., Arsianti A., Kurniawaty, E., Ismail, I., S., Batubara I., Audah., K., A. 2021. Evaluation of Indonesian mangrove Xylocarpus granatum leaves ethyl acetate extract as potential anticancer drug. Scientific Reports. 11, pp.6080.

[8] Das, G., Gouda, S., Mohanta, Y. K., and Patra, J. K. 2015. Mangrove plants: A potential source for anticancer drugs. Indian Journal of Geo-Marine Sciences. 44(5), pp.666-672.

[9] Ganora, L. ed. 2009. Herbal constituents. Louisville. Colo: Herbalchem Press.

[10] Grigalius, I., and Petrikaite, V. 2017. Relationship between Antioxidant and Anticancer Activity of Trihydroxyflavones. Molecules. 22, pp.2169.

[11] Gullett, N. P., Hebbar, G., and Ziegler, T. R. 2010. Update on clinical trials of growth factors and anabolic steroids in. Current Opinion in Clinical Nutrition and Metabolic Care. 91, pp.1143-1147.

[12] Huang, C. Y., Ju, D. T., Chang, C. F., Muralidhar R., P., and Velmurugan, B. K. 2017. A review on the effects of current chemotherapy drugs and natural agents in treating non-small cell lung cancer. BioMedicine (France). 7(4), pp.12-23. https://doi.org/10.1051/bmden/2017070423.

[13] Iqbal, J., Abbasi, B. A., Mahmood, T., Kanwal, S., Ali, B., Shah, S. A., and Khalil, A. T. 2017. Plantderived anticancer agents: A green anticancer approach. Asian Pac J Trop Biomed. 7(12), pp.1129-1150.

[14] Jun, M., Fu, H.Y., Hong., J., Wan, X., Yang, C.S., and Ho, C.T. 2003. Comparison of Antioxidant Activities of Isoflavones from Kudzu Root (Pueraria labata Ohwi). J Food Sci Technol. 68(6), pp.211722.

[15] Harwig, J and Scott, P.M. Brine shrimp (Artemia salina L.) larvae as a screening system for fungal toxins. Appl Microbiol. 1971 Jun; 21(6), pp.1011-6.

[16] Mosmann T. Rapid colorimetric assay for cellular growth and survival: Application to proliferation an cytotoxicity assays. Journal of Immunological Methods. 1983;65(1-2), pp.:55-63.

[17] Khafagi, I., Alla A.G., Salama W., and Fouda M. 2003. Biological Activities and Phytochemical Constituents of The Gray Mangrove Avicennia marina (Forssk.) Vierh. Egyptian. J. Biol. 5, pp.6269.

[18] Kusmana, C., and Sukristijiono. 2016. Mngrove Resource Uses by Local Community in Indonesia. 
Jurnal Pengelolaan Sumberdaya Alam dan Lingkungan. 6(2), pp.217-224.

[19] Manuella, K., Audah, K. A., and Sutanto, H. 2016. Evaluation of Antioxidant Activity of Mangrove Tree Rhizopora mucronata Leaf Extract. BS Thesis. Department of Biomedical Engineering. Swiss German University, Tangerang, Indonesia.

[20] Newman, D. J., and Cragg, G. M. 2016. Natural Products as Sources of New Drugs from 1981 to 2014. Journal of Natural Products. 79(3), pp.629661.

[21] Nisar, B., Sultan, A., and Rubab, S. L. 2018. Comparison of Medicinally Important Natural Products versus Synthetic Drugs-A Short Commentary. Natural Products Chemistry \& Research. 06(02).

[22] Nordin, M. L., Abdul Kadir, A., Zakaria, Z. A., Abdullah, R., and Abdullah, M. N. H. 2018. In vitro investigation of cytotoxic and antioxidative activities of Ardisia crispa against breast cancer cell lines, MCF-7 and MDA-MB-231. BMC Complementary and Alternative Medicine. 18(1).

[23] Qusti, S. Y., Abo-khatwa, A. N., Lahwa, M., and Bin. A. 2010. Screening of Antioxidant Activity and Phenolic Content of Selected Food Items Cited in the Holly Quran. European Journal of Biological Sciences. 2(1), pp.40-51.

[24] Sukhramani, P. S., and Patel, P. M. 2013. Biological screening of Avicennia marina for anticancer activity. Der Pharmacia Sinica. 4(2), pp.125-130.

[25] Sung, H., Ferlay, J., Siegel, R. L., Laversanne, M., Soerjomataram, I., Jemal, A., Bray, F. 2021. Global cancer statistics 2020: GLOBOCAN estimates of incidence and mortality worldwide for 36 cancers in 185 countries. CA: A Cancer Journal for Clinicians. 0(0). pp.1-41. https://doi.org/10.3322/caac.21660.

[26] Wang, T., Li, Q., and Bi, K. 2018. Bioactive flavonoids in medicinal plants: Structure, activity and biological fate. Asian Journal of Pharmaceutical Sciences. 13(2018), pp.12-23 